Canadian Journal of Higher Education

Revue canadienne d'enseignement supérieur

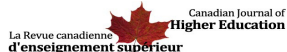

\title{
Book review of "Vocational Education in Canada: The Past, Present and Future of Policy"
}

Hans G. Schuetze

Volume 48, Number 2, 2018

URI: https://id.erudit.org/iderudit/1057113ar

DOI: https://doi.org/10.7202/1057113ar

See table of contents

Publisher(s)

Canadian Society for the Study of Higher Education

ISSN

2293-6602 (digital)

Explore this journal

Cite this review

Schuetze, H. (2018). Review of [Book review of "Vocational Education in Canada: The Past, Present and Future of Policy"]. Canadian Journal of Higher Education / Revue canadienne d'enseignement supérieur, 48(2), 194-196. https://doi.org/10.7202/1057113ar viewed online.

https://apropos.erudit.org/en/users/policy-on-use/ 


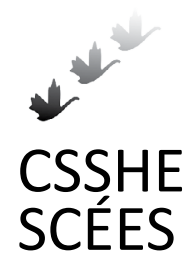

Canadian Journal of Higher Education Revue canadienne d'enseignement supérieur

Volume 48, No. 2, 2018, pages $194-196$

\section{Book Review / Compte rendu}

\section{Taylor, Alison (2016). Vocational Education in Canada: The Past, Pres- ent and Future of Policy. Don Mills, ON: Oxford University Press. Pages: 140. Price: 19.95 CDN (paper).}

Reviewed by Hans G. Schuetze, UBC Vancouver.

Over the last decades most higher education systems world-wide have adopted similar structures, partly because of explicit reforms (like the 48 European member countries of the so-called Bologna process, which have agreed to common structures and related policies), and partly by individual institutions emulating successful "world-class" universities, mostly from the US and the UK.

No similar efforts have been made for reforming vocational education and training (VET) by creating joint structures or standards, neither in Europe nor in other world regions. Or rather, there have been attempts by several countries at reforming vocational education by trying to emulate successful foreign models, for example the apprenticeship system of the German-speaking countries. However, such VET reforms have proven to be much more difficult than higher education reform because of their complexity and the wide variety of models and systems of education and training that are preparing young people for the world of work.

History and ideological understandings of the proper role of the state and the private sector (the employers) explain both why VET is organized so differently in various countries and why the sector has been long resistant to reforms that would provide greater harmonization of standards, and hence mobility of skilled workers between countries, or between federal states within the same country.

In Canada, two basic models of vocational education and training co-exist: a secondary school (high school) based system and a post-secondary "dual" system that combines community college learning with practical training at individual employers' premises.

Most provinces offer high school apprenticeship programs, cooperative education, work experience, and dual credit programs. In spite of reforms in some provinces, enrolments in these secondary school programs are uniformly low across the country: Less than five percent of overall high school enrolments are in such programs. The same is true for the post-secondary apprenticeship scheme, and even Quebec's General and Vocational College (CEGEP) system attracts less than ten percent of youth to its VET track programs. 
Taylor explains why Canada has historically relied on immigration of skilled workers rather than developing a major VET sector, starting with the recruitment of Chinese rail workers in the 1880 s to importing crafts people from Europe at the beginning of the 2oth century and Asian IT and service workers in the latter part of that century. The more academic forms of post-secondary education (universities and colleges) were the "gold standard" for young people and their parents, with the consequence that VET was considered second class and in-school vocational programs in Canada tended to be stigmatized as being primarily for "at-risk" students and low academic achievers.

Especially informative for Canadian readers will be Taylor's comparison of the Canadian VET system with that of Germany, where about half of the youth cohort choose apprenticeship training at the end of lower secondary education. While the practice-based learning ("training") takes place at actual workplaces, all Länder [provinces] have special upper-secondary vocational schools that apprentices must attend for the theoretical part of learning. Although Germany, like Canada is a federal country where the constitution gives to the Länder the legislative responsibility for education and hence vocational schools, the federal government, unlike in Canada, has the power, derived from its responsibility for economic development, to regulate skills training. The federal Vocational Training Act sets high standards and enforces these with the help of chambers of industry (or of craft trades) of which all private firms must be members.

Taylor shows how different traditions (apprenticeships and the chambers have their medieval precursors) and legal frameworks in the two countries explain the differences in their approach to skill training - and the difficulty of adapting the model of the Germanspeaking countries in Canada (or other countries in the Anglo-Saxon tradition). Moreover, the absence of the federal government in the formulation of a pan-Canadian VET policy and of national standards for education and training prevents the adaption of a coherent strategy of vocational education.

The Germanic dual apprenticeship system is seen by many analysts as the reason why these countries have better school-to-work transition, and therefore experience less youth unemployment. It is also seen as the main factor why dual training countries are economically successful, because of the availability of a large, well trained workforce. However, Taylor finds that this form of preparing youth for their lives as skilled workers has its price: Early tracking and the division of vocational bound and academic track students leads to a "devaluation of practical education and manual occupations" (p. 79). She argues that "all youth would benefit from more integrated formal and informal work-based learning opportunities through their compulsory and post-compulsory schooling" (p. 83).

The book provides not just insights about the history and present state of school based vocational education in Canada but discusses also some normative questions that need to be answered regarding the challenge of "social justice" and the future of vocational education. For example, what role should schools play in preparing youth for working life? Should schools train youth for specific jobs, or develop more general academic skills? How has work changed in recent decades, and what does that mean for skills and vocational education and training in a "knowledge-based economy"? What responsibilities should the state (schools) have, and what responsibility do employers have for skills training in general and for training their (future) employees in particular? 
Taylor's focus is primarily on school apprenticeship programs, cooperative education, work experience, and dual credit opportunities for students. Her data are primarily from Ontario, Canada's most populous province, and the western province of Alberta, which has some interesting innovative organizational features of vocational education and training. Her discussion, partly based on her own empirical studies, is very interesting, raising questions about possible futures for vocational education and training. However, one would have liked to read a bit more about VET policies and practice in other provinces, especially Quebec with its unique CEGEP system.

Nonetheless, because of its empirical basis and its comparative analytic perspective, this book is highly recommended: It should be read by both scholars and policy makers interested in the history, present, and future of secondary and post-secondary education and training. 